\title{
Influential Factors on Customer Satisfaction: Case of Branded Fast Food Outlet in Jammu City
}

\author{
Ashish Kumar Isher*, Rohit Kumar, Jyoti Kachroo, Sudhakar Dwivedi, \\ Anil Bhat and Sabbey Sharma
}

Division of Agricultural Economics and ABM, SKUAST-Jammu, J\&K (UT), India

"Corresponding author: ashishisher222@gmail.com (ORCID ID: 0000-0002-5628-5725)

Paper No. 878

Received: $10-01-2021$

Revised: 21-02-2021

Accepted: 11-03-2021

\begin{abstract}
The paper entitled "Influential Factors on Customer Satisfaction: Case of Branded Fast Food Outlet in Jammu City" was carried out in Jammu city of J\&K (UT). The research adopted a convenience sampling technique to carry out the survey. The primary data was collected from 100 respondents by filling up the pre-tested schedule-cum-questionnaire. The major findings of the study show that the factors like hospitality, advertisement, and price of the food at the branded retail outlets influence the overall customer satisfaction.

\section{Highlights}

(0 Majority of the respondents visiting the food outlet were satisfied with the pricing factor, preparation time, and environment of the outlet.

( Customers visiting the outlet were having a tendency towards vegetarian food as compared to nonvegetarian foods.

( Factors greatly influencing the customers' satisfaction level were hospitality of the staff and advertisement attractiveness.
\end{abstract}

Keywords: customer satisfaction, advertisement, branded, behavior

In today's world, Fast food or junk food is something that almost everyone, right from kids to adults, loves. Fast food is one of the world's fastest growing food types. Fast foods are time saver, reasonably priced, and readily available alternatives to homecooked food. The escalation in the number of nuclear families, particularly in urban India, exposure to worldwide media and Western cuisine, and a mounting number of women joining the workforce has to lead us to an era of eating- 'fast food'. At present, in India, organized retail chains are driving the changes in the food chain. The main reason behind the success of the multinational chains is their proficiency in product development, sourcing practices, quality standards, service levels, and standardized operating procedures in their restaurants, which they have build up the Fast food Industry in India. Customer satisfaction is very pivotal in the food industry as, according to Deng et al. (2009) for a service provider to differentiate its product and develop a strong relationship with customers, it is essential to create a high degree of satisfaction is essential. In 2010, Lim is his research revealed that for a customer, it is not essential that better quality can be a better taste if a customer feels satisfied by the taste of the food he will be willing to pay for it. It was found that there is a significant correlation found between customer satisfaction and taste. Good taste of food has a constructive effect on customers' satisfaction, and it also enhances the customer's retention rate, which also depends upon satisfaction. Therefore, the restaurant's focal point is the taste of the food and services as it has an influence on customers' satisfaction.

How to cite this article: Isher, A.K., Kumar, R., Kachroo, J., Dwivedi, S., Bhat, A. and Sharma, S. 2021. Influential Factors on Customer Satisfaction: Case of Branded Fast Food Outlet in Jammu City. IJAEB, 14(1): 17-20.

Source of Support: None; Conflict of Interest: None 


\section{Objective}

To study the influential factors affecting customer satisfaction towards Domino's pizza outlet in Jammu City.

\section{MATERIAL AND METHODS}

Participants: The research was conducted in the local areas in Jammu city. The sample size was 100, which incorporated people from various age groups and different income levels visiting the outlet of Domino's.

Tool used: 5 points Likert scale was used to record the responses of the respondents.

Statistical Analysis: After collecting the data, the results are analyzed by using the percentage method and Garrett ranking technique.

$$
\text { Percentage }=(\mathrm{x} / \mathrm{y}) \times(100 / 1)
$$

Where $x$ = number of respondents respond

$Y=$ total number of respondents

\section{Henry Garret ranking technique:}

Percentage position $=100\left(R_{i j}-0.5\right) / n$

Where $R_{i j}$ is the rank, $N=$ number of items

Procedure: The primary data was collected with the help of a schedule/questionnaire based on the information collected from the customers visiting the Domino's pizza outlets in Jammu city, while the secondary data was collected from various journals, websites, and other sources.

\section{RESULTS AND DISCUSSION}

Table 1 shows the demographics of respondents taken for the study. It is clear from the table that out of total respondents, 39.00 percent lies in the income range of ₹ $10000-20000$, followed by the 24.00 percent respondents who lie in the income range of below ₹ 10000 , followed by the 21.00 percent respondents which lie in the income range of ₹ 20000-30000 and 16.00 percent respondents which lie in the income range of $₹ 30000$. The data also shows that a maximum number of the respondents i.e., 49.00 percent were graduates, followed by 29.00 percent who were -post-graduate and 22.00 percent were undergraduate. The figure also reveals the occupational aspect of the sample as it depicts clearly that 42.00 percent were employees, 36.00 percent were students, 18.00 percent were self-employed, and 4.00 percent were from other occupations.

Table 1: Demographics Details of the Respondents

\begin{tabular}{llll}
\hline Demographics & Frequency & Percentage \\
& Below ₹ 10000 & 24 & 24.00 \\
Monthly & $₹ 10000-₹ 2000039$ & 39.00 \\
Income Level & $₹ 20000-₹ 30000$ & 21 & 21.00 \\
& Above ₹ 30000 & 16 & 16.00 \\
Educational & Under graduate & 22 & 22.00 \\
Qualification & Graduate & 49 & 49.00 \\
& Post Graduate & 29 & 29.00 \\
& Students & 36 & 36.00 \\
Occupation & Employees & 42 & 42.00 \\
& Self employed & 18 & 18.00 \\
& Others & 4 & 4.00 \\
\hline
\end{tabular}

Table 2 represents the kind of food that the consumers prefer in Domino's. 68.00 percent of consumers prefer vegetarian food and only 32.00 percent respondents prefer non-vegetarian food. Thus tendency towards vegetarian food is more a compared to non-vegetarian foods.

Table 2: Kind of Preferred Food by Consumers

\begin{tabular}{lll}
\hline Preferred food & Frequency & Percentage \\
\hline Vegetarian & 68 & 68.00 \\
Non-Vegetarian & 32 & 32.00 \\
\hline
\end{tabular}

Table 3 represents the satisfaction level of consumers towards vegetarian food products. It was revealed from the table that regarding pizza, 25 percent were highly satisfied, 55.88 percent were satisfied, 19.12 percent were moderately satisfied, and none $(0$ percent) was dissatisfied with the Domino's pizza. Regarding the Domino's vegetarian burgers, 17.65 percent were highly satisfied, 47.06 percent were satisfied, 27.94 percent were moderately satisfied, and 7.35 percent were dissatisfied. Regarding the pasta served at Domino's, 19.12 percent were highly satisfied, 66.18 percent were satisfied, 14.71 percent were moderately satisfied, and none ( 0 percent) were dissatisfied. Regarding the cheese dips of Domino's, none (0 percent) was highly satisfied, 22.06 percent were satisfied, 35.29 percent were moderately satisfied, and 25 percent were dissatisfied, and 17.65 
Table 3: Consumer Satisfaction towards Vegetarian Products

\begin{tabular}{|c|c|c|c|c|c|c|c|c|c|c|}
\hline \multirow[b]{2}{*}{ Products } & \multicolumn{5}{|c|}{ Frequency } & \multicolumn{5}{|c|}{ Percentage } \\
\hline & $\begin{array}{l}\text { Highly } \\
\text { satisfied } \\
(5)\end{array}$ & $\begin{array}{l}\text { Satisfied } \\
\text { (4) }\end{array}$ & $\begin{array}{l}\text { Moderate } \\
\text { (3) }\end{array}$ & $\begin{array}{l}\text { Dissatisfied } \\
\text { (2) }\end{array}$ & $\begin{array}{l}\text { Highly } \\
\text { dissatisfied } \\
\text { (1) }\end{array}$ & $\begin{array}{l}\text { Highly } \\
\text { satisfied } \\
(5)\end{array}$ & $\begin{array}{l}\text { Satisfied } \\
\text { (4) }\end{array}$ & $\begin{array}{l}\text { Moderate } \\
\text { (3) }\end{array}$ & $\begin{array}{l}\text { Dissatisfied } \\
\text { (2) }\end{array}$ & $\begin{array}{l}\text { Highly } \\
\text { dissatisfied } \\
\text { (1) }\end{array}$ \\
\hline Pizza & 17 & 38 & 13 & 0 & 0 & 25.00 & 55.88 & 19.12 & 0.00 & 0.00 \\
\hline Burger & 12 & 32 & 19 & 5 & 0 & 17.65 & 47.06 & 27.94 & 7.35 & 0.00 \\
\hline Pasta & 13 & 45 & 10 & 0 & 0 & 19.12 & 66.18 & 14.71 & 0.00 & 0.00 \\
\hline $\begin{array}{l}\text { Cheese } \\
\text { dips }\end{array}$ & 0 & 15 & 24 & 17 & 12 & 0.00 & 22.06 & 35.29 & 25.00 & 17.65 \\
\hline
\end{tabular}

Table 4: Consumer Satisfaction towards Non-vegetarian Products

\begin{tabular}{|c|c|c|c|c|c|c|c|c|c|c|}
\hline \multirow[b]{2}{*}{ Products } & \multicolumn{5}{|c|}{ Frequency } & \multicolumn{5}{|c|}{ Percentage } \\
\hline & $\begin{array}{l}\text { Highly } \\
\text { satisfied } \\
\text { (5) }\end{array}$ & $\begin{array}{l}\text { Satisfied } \\
(4)\end{array}$ & $\begin{array}{l}\text { Moderate } \\
\text { (3) }\end{array}$ & $\begin{array}{l}\text { Dissatisfied } \\
\text { (2) }\end{array}$ & $\begin{array}{l}\text { Highly } \\
\text { dissatisfied } \\
\text { (1) }\end{array}$ & $\begin{array}{l}\text { Highly } \\
\text { satisfied } \\
\text { (5) }\end{array}$ & $\begin{array}{l}\text { Satisfied } \\
\text { (4) }\end{array}$ & $\begin{array}{l}\text { Moderate } \\
\text { (3) }\end{array}$ & $\begin{array}{l}\text { Dissatisfied } \\
\text { (2) }\end{array}$ & $\begin{array}{l}\text { Highly } \\
\text { dissatisfied } \\
\text { (1) }\end{array}$ \\
\hline Pizza & 4 & 8 & 20 & 0 & 0 & 12.50 & 25.00 & 62.50 & 0.00 & 0.00 \\
\hline Burger & 2 & 21 & 9 & 0 & 0 & 6.25 & 65.63 & 28.13 & 0.00 & 0.00 \\
\hline Pasta & 3 & 20 & 9 & 0 & 0 & 9.38 & 62.50 & 28.13 & 0.00 & 0.00 \\
\hline $\begin{array}{l}\text { Chicken } \\
\text { wings }\end{array}$ & 4 & 16 & 12 & 0 & 0 & 12.50 & 50.00 & 37.50 & 0.00 & 0.00 \\
\hline
\end{tabular}

percent were highly dissatisfied with the cheese dips of Domino's.

Table 4 represents the satisfaction level of consumers towards non-vegetarian food products. With the non-vegetarian pizzas, 12.50 percent were highly satisfied, 25 percent were satisfied, and 62.50 percent were moderately satisfied. Regarding the burger, 6.25 percent were highly satisfied, 65.63 percent were satisfied, and 28.13 percent were moderately satisfied. Regarding the non-vegetarian pasta, 9.38 percent were highly satisfied, 62.50 percent were satisfied, and 28.13 percent were moderately satisfied. Regarding the chicken wings, 12.50 percent of respondents were highly satisfied, 50 percent were satisfied, and 37.50 percent were moderately satisfied.

Garret's ranking technique was used to determine the most important factor affecting customer satisfaction. Table 5 revealed that the hospitality ranks number I, followed by advertisement attractiveness, overall satisfaction towards the restaurant, Price of food, preparation time, the environment of the place, quality of the food, variety of foods, the freshness of the food, home delivery services, taste of the food at II, III,IV,V,VI,VII,VIII,IX, $\mathrm{X}$ and XI positions respectively.
Table 5: Rank wise Response towards Factors Influence Customer Satisfaction

\begin{tabular}{llll}
\hline Factors & Total & $\begin{array}{l}\text { Average } \\
\text { score }\end{array}$ & Rank \\
\hline Price of food & 6184 & 61.84 & IV \\
Quality of food & 6098 & 60.98 & VII \\
Taste of food & 5948 & 59.48 & XI \\
Freshness of the food & 6036 & 60.36 & IX \\
Preparation Time & 6132 & 61.32 & V \\
Hospitality of the staff & 6264 & 62.64 & I \\
Environment of Domino's & 6106 & 61.06 & VI \\
Advertisement attractiveness & 6238 & 62.38 & II \\
Home delivery of food & 6028 & 60.28 & X \\
Overall satisfaction towards & 6198 & 61.98 & III \\
restaurant & & & \\
Variety of foods & 6056 & 60.56 & VIII \\
\hline
\end{tabular}

\section{CONCLUSION}

Domino's is among the leading fast-food chains. From the study, it is concluded tendency towards vegetarian food is more a compared to -nonvegetarian foods. The study also revealed that respondents were satisfied with the factors like pricing, preparation time, and environment of the outlet, but the major factors which greatly influence the satisfaction level of the customers visiting the outlet were hospitality of the staff and advertisement attractiveness. 


\section{REFERENCES}

Deng, Z., Lu, Y, Wei, K. K., Zhang, J. 2009. “Understanding customer satisfaction and loyalty: An empirical study of mobile instant messages in China", Inte. J. Inf. Manag., 30: 289-300.

Kotler, P. and Keller, K. 2006. Prentice-Hall, edition, Mark. Manag., 12: 1-718.

Lim, H. 2010. Understanding American customer perceptions on Japanese food and services in the U.S. UNLV Thesis/ Dissertations/Professional Papers/ Capstones, pp. 1-45.

Mohsan, F., Nawaz, M.M., Khan, M.S., Shallkat, Z. and Aslam, N. 2011. Impact of customer satisfaction on customer loyalty and intentions to switch: Evidence from banking sector of Pakistan. Int. J. Bus. Soc. Sci., 2(1): 16.

Rajasekaran, B. and Saravanan, P.A. 2014. Consumer Satisfaction on Fast Moving Consumer Goods. Glob. J. Res. Anal., 2(8): 38-41.
Ranaweera, C. and Prabhu, J. 2003. The influence of satisfaction, trust and switching barriers customer retention in a continuous purchasing setting. Int. J. Serv. Ind. Manag., 14(1): 37-95.

Schiffman, L.G. and Kanuk, L.L. 2004. Consumer Behaviour. J. Bus. Manag. Sci., 4(4): 76-81.

Thorsten, H.T. and Alexander, K. 1997. The impact of customer satisfaction and relationship quality on customer retention: A critical reassessment and model development. Psychol. Mark., 14(8): 737-764.

Zairi, M. 2000. Managing customer dissatisfaction through effective complaint management systems. The TQM Magazine, 12(5): 331-335.

Zeithaml, V.A. and Bitner, M.J. 2003. Service Marketing: Integrating Customer Focus Across the Firm, New York: McGraw-Hill Higher Education. 